\title{
Antidiarrheal Activity of Ethanolic Extract of Melochia corchorifolia L. and Glochidion thomsonii in Experimental Animal Models
}

\author{
Nusrat Jahan ${ }^{1}$, Jannatul Ferdousi ${ }^{1}$, Md. Jahir Alam ${ }^{1}$, Tasmina Rahman ${ }^{1}$, \\ Mizanur Rahman ${ }^{2}$ and Masum Shahriar ${ }^{1}$
}

\author{
${ }^{1}$ Department of Pharmacy, Jahangirnagar University, Savar, Dhaka, Bangladesh \\ ${ }^{2}$ Department of Pharmacy, Daffodil International University, Dhaka, Bangladesh
}

(Received: March 9, 2019; Accepted: April 28, 2019; Published: July 22, 2019)

\begin{abstract}
Diarrhoea is a public health problem in developing countries. It is therefore important to identify plants with antidiarrhoeal activity. Melochia corchorifolia and Glochidion thomsonii have been used in folk medicine to alleviate several diseases. The present study was performed to investigate the anti-diarrheal properties of ethanolic extract of $M$. corchorifolia whole plant and G. thomsonii bark. Anti-diarrheal potential was evaluated using castor oil and $\mathrm{MgSO}_{4}$ induced diarrhea, GI motility test as well as castor oil induced enteropooling assay in mice. Extracts were used at 250 and $500 \mathrm{mg} / \mathrm{kg}$ per orally. Loperamide (10 mg/kg p.o) was used as standard drug. The ethanolic crude extracts exhibited statistically significant and dose-dependent $(250$ and $500 \mathrm{mg} / \mathrm{kg})$ anti-diarrheal effect against the total number of episodes of defecation as well as diarrheal feces. In animals pretreated with MC and GT extract showed $42.53 \%(\mathrm{p}<0.05)$ and $53.13 \%(\mathrm{p}<0.001)$ protection at a dose of $250 \mathrm{mg} / \mathrm{kg}$ and $89.40 \%$ $(\mathrm{p}<0.001)$ and $57.47 \%(\mathrm{p}<0.001)$ protection at $500 \mathrm{mg} / \mathrm{kg}$ against castor oil induced diarrhea. The MC extract at $500 \mathrm{mg} / \mathrm{kg}$ exhibited significant $(\mathrm{p}<0.05)$ inhibition of diarrhea $(51.04 \%)$ in $\mathrm{MgSO}_{4}$ induced diarrhea. In $\mathrm{BaSO}_{4}$ induced GI motility test both the extracts inhibited GI motility and GT at $500 \mathrm{mg} / \mathrm{kg}$ dose $38.77 \%$ which was highly significant $(\mathrm{p}<0.01)$. In the Castor oil induced enteropooling assay MC 250 and $500 \mathrm{mg} / \mathrm{kg}$ and GT 250 and $500 \mathrm{mg} / \mathrm{kg}$ reduced the intestinal fluid accumulation by $27.42 \%$ and $48.39 \%(p<0.01)$ and $38.71 \%(p<0.05)$ and $51.61 \%(p<0.01)$, respectively. The results suggested that both the extracts possessed significant antidiarrhoeal properties which was comparable with standard drug, loperamide and further studies are required to evaluate these effects and the potential of the plant.
\end{abstract}

Key words: Melochia corchorifolia, Glochidion thomsonii, Castor oil induced diarrhea, $\mathrm{BaSO}_{4}$, Enteropooling assay.

\section{Introduction}

Gastrointestinal diseases, particularly constipation and diarrhea are affecting $70 \%$ of the population worldwide (Ouyangand Chen, 2004). Diarrhea is an alteration in normal bowel movement and is characterized by an increase in the water content, volume, or frequency of stools (Guerrant et al., 2001). It is a common disease in developing countries especially in children and is responsible for the death of millions of people each year which is accounted as the second leading causes of death of children below five years (Jebunnessa et al., 2009; Saralaya et al., 2010). The incidence of diarrhoeal diseases still remains high despite the efforts of many governments and healthcare organizations. Many crude plant extracts with antidiarrhoeic activity are used in our folk medicine and are a potential source of antidiarrheal drugs because they contain multiple constituents with effect-enhancing and/or side effectneutralizing potential (Laloo and Hemalatha, 2011; Gilani and Rahman, 2005). Medicinal plants are a promising source of antidiarrheal drugs (Maikere-

Correspondence to: Masum Shahriar; E-mail: masum_shahriar@juniv.edu

DOI: https://doi.org/10.3329/bpj.v22i2.42304 
Faniyo et al., 1989). It is therefore important to identify and evaluate available natural drugs as alternatives to currently used anti-diarrhoeal drugs, which are not always free from adverse effects. A range of medicinal plants with anti-diarrhoeal properties is widely used by traditional healers. However, the effectiveness of many of these antidiarrhoeal traditional medicines has not been scientifically evaluated.

Melochia corchorifolia L (Bon-pat and Tikiokra in Bengali) is a weed-like, tropical plant of Malvaceae familly that is typically seen in the wastelands. It has been most frequently observed to grow in North Carolina, Africa, Asia, Australia, and South western Pacific (Compendium of Medicinal Plants Used in Malaysia. 2002). It has ovate leaves; the petioles are generally $5 \mathrm{~cm}$ long with linear stipules of $6 \mathrm{~mm}$ long. It contains several compounds cyclopepetide alkaloids franganine, frangufoline (Tschesche and Reutel, 1968), melofoline, melochicorine and other constituents (Bhakuni et al., 1991; Bhakuni et al., 1987). Various parts of the plant have been used to treat stomach disorders, stomachache (Raja et al., 2001), poulticing sores, swellings of the abdomen, smallpox, dysentery, vomiting, urinary disorders, water snake bites (Chopra et al., 1956), headache, gastralgia and as helmenthiasis in the traditional and folk medicine (Ajaib et al., 2010).

Glochidion thomsonii Hook. $\mathrm{f}$, belonging to the euphorbiaceae family, also known as Phyllanthus thomsonii, Glochidion rubidulum and Diasperus thomsonii is a shrub of forest, non-marine, scrubland (www.gbif.org). It is found in Bangladesh, NorthEast India, in the Jaintia Hills, Meghalaya, China and Sri Lanka (www.efloras.org). There are no available reports on the phytochemical as well as pharmacological study on this plant.

As a part of our broad-based search for Bangladeshi medicinal plants with antidiarrheal activity, the present study was undertaken to evaluate the possible usefulness of M. corchorifolia (MC) and G. thomsonii (GT).

\section{Materials and Methods}

Plant collection and extraction: The whole plant of $M$. corchorifolia (MC) and bark of G. thomsonii (GT) were collected from Sylhet, and Dhaka district and were identified and authenticated by the National Herbarium, Mirpur, Dhaka (Acc No. DACB 40843 for MC and DACB 40169 for GT). The collected materials were thoroughly washed in water, cut into smaller parts and shed dried at $35-40^{\circ} \mathrm{C}$ for a week and pulverized in electric grinder to get extractable powder. The powders were extracted in Soxhlet apparatus with ethanol (96\%). The collected filtrate was dried with a rotary evaporator under reduced pressure to get viscous substance. Finally, a solid mass was obtained and preserved in a glass container in the refrigerator.

Experimental animals: For the experiment Swiss albino mice of either sex, 6-7 weeks of age, weighing between 25-30 g were collected from the animal research lab in the Department of Pharmacy, Jahangirnagar University, Savar, Dhaka. Animals were maintained under standard environmental conditions (temperature: $27.0 \pm 1.0^{\circ} \mathrm{C}$, relative humidity: $55-65 \%$ and $12 \mathrm{~h}$ light/12 h dark cycle) and had free access to feed and water ad libitum. The animals were acclimatized to laboratory condition for one week prior to the experiments. For conducting all experiments with animals, we followed the guidelines of Institutional Animals Ethics Committee (IAEC) and before the experiments, study protocols were approved by the institutional animal ethical committee.

\section{Anti-diarrheal activity evaluation}

Castor oil induced diarrhea in mice: The method as described by Jebunnessa et. al. (2009) and Imam (2012) was used with slight modification to evaluate anti-diarrheal activity of the plant extracts. Thirty-six mice fasted for 12 hours were allocated to six groups of six animals each. Group I (received distilled water (DW) at a dose of $10 \mathrm{ml} / \mathrm{kg}$ p.o.) and served as control group, group II (received loperamide 10 $\mathrm{mg} / \mathrm{kg}$, p.o.) and served as standard, group III, IV, V \& VI received the ethanolic extract of $M$. corchorifolia at $250 \mathrm{mg} \& 500 \mathrm{mg}$, G. thomsonii at $250 \mathrm{mg}$ and $500 \mathrm{mg} / \mathrm{kg}$ p.o., respectively. One hour 
after administration, mice were administered with castor oil orally at a dose of $0.5 \mathrm{ml}$ per mouse to induce diarrhea. Each animal was placed in an individual cage, the floor of which was lined with white blotting paper which was changed every hour. The total number of both dry and wet feces excreted by the animals was counted every hour for a period of 4 hours. The activity of each group was expressed as percent inhibition (\%) of defecation and percent inhibition $(\%)$ of diarrhea.

Magnesium sulfate-induced diarrhea in mice: Thirty-six mice of either sex fasted for 12 hours were divided into six groups of 6 mice each. Group 1 was given distilled water $(10 \mathrm{ml} / \mathrm{kg})$, while group 2 received loperamide $(10 \mathrm{mg} / \mathrm{kg})$. Groups 3, 4, 5 and 6 were administered with MC $250 \mathrm{mg}$, MC $500 \mathrm{mg}$, GT $250 \mathrm{mg}$ and GT $500 \mathrm{mg} / \mathrm{kg}$ b.w., respectively. All treatments were given orally. After 1 hour, each mouse received magnesium sulfate $(2 \mathrm{~g} / \mathrm{kg})$ by oral route. The animals were placed individually in cages over white filter paper. The number of wet feces was recorded for a period of 4 hours (Doharty, 1981). The activity of each group was expressed as percent inhibition (\%) of defecation and percent inhibition $(\%)$ of diarrhea.

Gastrointestinal motility test with barium sulfate milk: The method described by Afroz et al. (2006) was followed with slight modification. Thirty-six mice of either sex fasted for 12 hours were divided into six groups of 6 mice each. Group 1 was given distilled water $(10 \mathrm{ml} / \mathrm{kg})$, while group 2 received loperamide $(10 \mathrm{mg} / \mathrm{kg})$. Groups 3, 4, 5 and 6 were administered with MC $250 \mathrm{mg}$, MC $500 \mathrm{mg}$, GT 250 $\mathrm{mg}$ and GT $500 \mathrm{mg} / \mathrm{kg}$ b.w., respectively. After 30 minutes, each mouse was administered $15 \%$ barium sulphate milk $(10 \mathrm{ml} / \mathrm{kg})$ by oral route. After 30 minutes of administration of barium sulfate milk, mice were sacrificed. The distance traversed by barium sulfate milk was measured and expressed as a percentage of the total length of small intestine. The percentage of inhibition of GI motility compared with the control group was determined by using the following equation:

$\%$ Inhibition of intestinal $=$ test extract control/control $\times 100$
Castor oil induced enter pooling: The method of Ezeja and Anaga (2010) and Sini et al. (2008) was followed with slight modification. Animals (mice of either sex weighing 30-35 g) were fasted for 12 hours and were randomly divided into six groups $(\mathrm{n}=6)$. First group received only vehicle (DW $10 \mathrm{~mL} / \mathrm{kg}$ ), second group received loperamide $(10 \mathrm{mg} / \mathrm{kg})$, the third, fourth, fifth and sixth group received MC 250 $\mathrm{mg} \&$ MC $500 \mathrm{mg}$, GT $250 \mathrm{mg}$ and GT $500 \mathrm{mg} / \mathrm{kg}$, p.o. After 1 hour from the administration, $0.5 \mathrm{ml}$ of castor oil was administered orally. Two hours later, all mice were sacrificed, the small intestine was ligated both at the pyloric sphincter and at the ileocecal junctions and the intestines were removed. The content of each intestine was collected by milking into a graduated measuring cylinder and the volume (ml) was measured.

Statistical analysis: Microsoft Office Excel (2007) was used as a statistical tool for diarrheal inhibition assay data and graph. Statistical analysis for animal experiments was carried out by one-way ANOVA following Dunnet's post hoc test using SPSS 16.0 for windows. Data were presented as Mean \pm SEM. The results obtained were compared with the vehicle control group. $\mathrm{p}<0.05, \mathrm{p}<0.01$ and $p<0.001$ were considered to be statistically significant, highly significant and very highly significant respectively.

\section{Results}

Castor oil-induced diarrhea: The castor oil induced diarrhea was carried out to assess the effect of ethanolic extract of $M$. corchorifolia (MC) and $G$. thomsonii (GT) in experimentally induced diarrhea in rodent. The results showed that, there has been a statistically significant reduction in the incident and severity of diarrhea with higher dose of the crude extract of MC and GT in experimental animals (Table 1).

At dose of $500 \mathrm{mg} / \mathrm{kg}$, both the plant extracts significantly $(\mathrm{p}<0.001)$ reduced diarrhea induced by castor oil when compared to the vehicle treated control group. Crude extract of MC and GT at 250 $\mathrm{mg} / \mathrm{kg}$ dose reduced the number of fecal episodes by 
$15.33 \%$ and $30.75 \%$ and reduced the diarrheal episodes by $42.53 \%$ and $53.13 \%$, respectively. Whereas, loperamide $(10 \mathrm{mg} / \mathrm{kg}$, p.o.) treated group showed a significant decrease compared to the control group $(\mathrm{p}<0.001)$

$\mathrm{MgSO}_{4}$-induced diarrhea: The results of the effect of $\mathrm{MC}$ and $\mathrm{GT}$ on $\mathrm{MgSO}_{4}$-induced diarrhea were observed and are shown in table 2. Ethanolic extract of MC and GT at $250 \mathrm{mg} / \mathrm{kg}$, p.o. showed no significant effect. At dose of $500 \mathrm{mg} / \mathrm{kg}$, both MC and GT extract significantly reduced the number of fecal episodes by $57.70 \%$ ( $<0.001)$ and $40.39 \%$ $(\mathrm{p}<0.01)$ and reduced the diarrheal episodes by $51.04 \%(\mathrm{p}<0.05)$ and $42.84 \%$, respectively when compared to the control group.

Table 1. Effect of ethanolic extract of MC and GT on castor oil induced diarrhea in rats.

\begin{tabular}{llcccc}
\hline Group & \multicolumn{1}{c}{ Sample } & $\begin{array}{c}\text { Total number of } \\
\text { feces } \\
\text { (Mean } \pm \text { SEM) }\end{array}$ & $\begin{array}{c}\text { \% Inhibition of } \\
\text { defecation }\end{array}$ & $\begin{array}{c}\text { Total number of } \\
\text { diarrhoeal feces } \\
\text { (Mean } \pm \text { SEM) }\end{array}$ & $\begin{array}{c}\text { \% Inhibition of } \\
\text { diarrhea }\end{array}$ \\
\hline Group-I & Control & $10.83 \pm 0.48$ & 00 & $7.83 \pm 0.66$ & 00 \\
Group-II & Standard & $2.33 \pm 0.67 * * *$ & 78.49 & $1.67 \pm 0.56^{* * *}$ & 78.67 \\
Group-III & MC 250 mg & $9.17 \pm 1.56$ & 15.33 & $4.50 \pm 1.06 *$ & 42.53 \\
Group-IV & MC 500 mg & $2.17 \pm 0.48^{* *}$ & 79.96 & $0.83 \pm 0.31 * * *$ & 89.40 \\
Group-V & GT 250 mg & $7.50 \pm 1.59$ & 30.75 & $3.67 \pm 0.67 * * *$ & 53.13 \\
Group-VI & GT 500 mg & $5.67 \pm 0.95 * *$ & 47.65 & $3.33 \pm 0.42 * * *$ & 57.47 \\
\hline
\end{tabular}

Data were analyzed by one-way ANOVA following Dunnet's post hoc test. Values are expressed as Mean \pm SEM, $n=6$. $*(p<0.05)=$ significant, $* *(p<0.01)=$ highly significant, $* * *(p<0.001)=$ very highly significant compared to the control group.

Table 2. Effect of ethanolic extract of $\mathrm{MC}$ and $\mathrm{GT}$ on $\mathrm{MgSO}_{4}$ induced diarrhea test in mice.

\begin{tabular}{llcccc}
\hline Group & \multicolumn{1}{c}{ Sample } & $\begin{array}{c}\text { Total number of } \\
\text { feces } \\
\text { (Mean } \pm \text { SEM) }\end{array}$ & $\begin{array}{c}\text { \% Inhibition of } \\
\text { defecation }\end{array}$ & $\begin{array}{c}\text { Total number of } \\
\text { diarrheal feces } \\
\text { (Mean } \pm \text { SEM) }\end{array}$ & $\begin{array}{c}\text { \% Inhibition of } \\
\text { diarrhea }\end{array}$ \\
\hline Group-I & Control & $17.33 \pm 1.76$ & 00 & $8.17 \pm 0.79$ & 00 \\
Group-II & Standard & $6.16 \pm 1.11^{* * *}$ & 64.45 & $1.67 \pm 0.40 * * *$ & 79.56 \\
Group-III & MC 250 mg & $13.17 \pm 1.45$ & 24.01 & $5.50 \pm 1.12$ & 32.68 \\
Group-IV & MC 500 mg & $7.33 \pm 0.56 * * *$ & 57.70 & $4.00 \pm 0.93 *$ & 51.04 \\
Group-V & GT 250 mg & $14.33 \pm 1.94$ & 17.31 & $7.0 \pm 1.15$ & 14.32 \\
Group-VI & GT 500 mg & $10.33 \pm 1.41^{* *}$ & 40.39 & $4.67 \pm 1.41$ & 42.84 \\
\hline
\end{tabular}

Data were analyzed by one-way ANOVA following Dunnet's post hoc test. Values are expressed as Mean \pm SEM, $\mathrm{n}=6$. $*(\mathrm{p}<0.05)=$ significant, $* *(\mathrm{p}<0.01)=$ highly significant, $* * *(\mathrm{p}<0.001)=$ very highly significant compared to the control group.

The standard drug loperamide $(10 \mathrm{mg} / \mathrm{kg}$, p.o.) profoundly ( $\mathrm{p}<0.001$ ), inhibited both the fecal output $(64.45 \%)$ and the diarrheal episodes $(79.56 \%)$ produced by magnesium sulfate. In terms of protection from fecal output at 4 hours, MC extract at $500 \mathrm{mg} / \mathrm{kg}$ dose was comparable with the effect of loperamide.
Effects of test extracts on gastrointestinal motility test: In this method, the mean distance travelled by the Barium sulfate in small intestine and $\%$ inhibition of intestinal motility was measured as compared with control group.

In the 'control' group of mice, the barium sulfate meal traversed the farthest distance of the total length 
of small intestine. Ethanolic extract of $\mathrm{MC}$ at both doses $(250 \mathrm{mg} / \mathrm{kg}$ and $500 \mathrm{mg} / \mathrm{kg}$ ) showed only slight reduction of GI motility when compared with the vehicle treated controls (Figure 1). MC 250- and 500$\mathrm{mg} / \mathrm{kg}$ reduced GI motility by 21.46 and $27.52 \%$, respectively. The extract of GT at dose $250 \mathrm{mg} / \mathrm{kg}$ also reduced the GI motility (10.20\%) whereas at 500 $\mathrm{mg} / \mathrm{kg}$ it inhibited the GI motility $(38.77 \%)$ significantly $(\mathrm{p}<0.01)$. Loperamide $(10 \mathrm{mg} / \mathrm{kg}$, p.o. $)$ produced a greater antimotility effect than both of the extract.

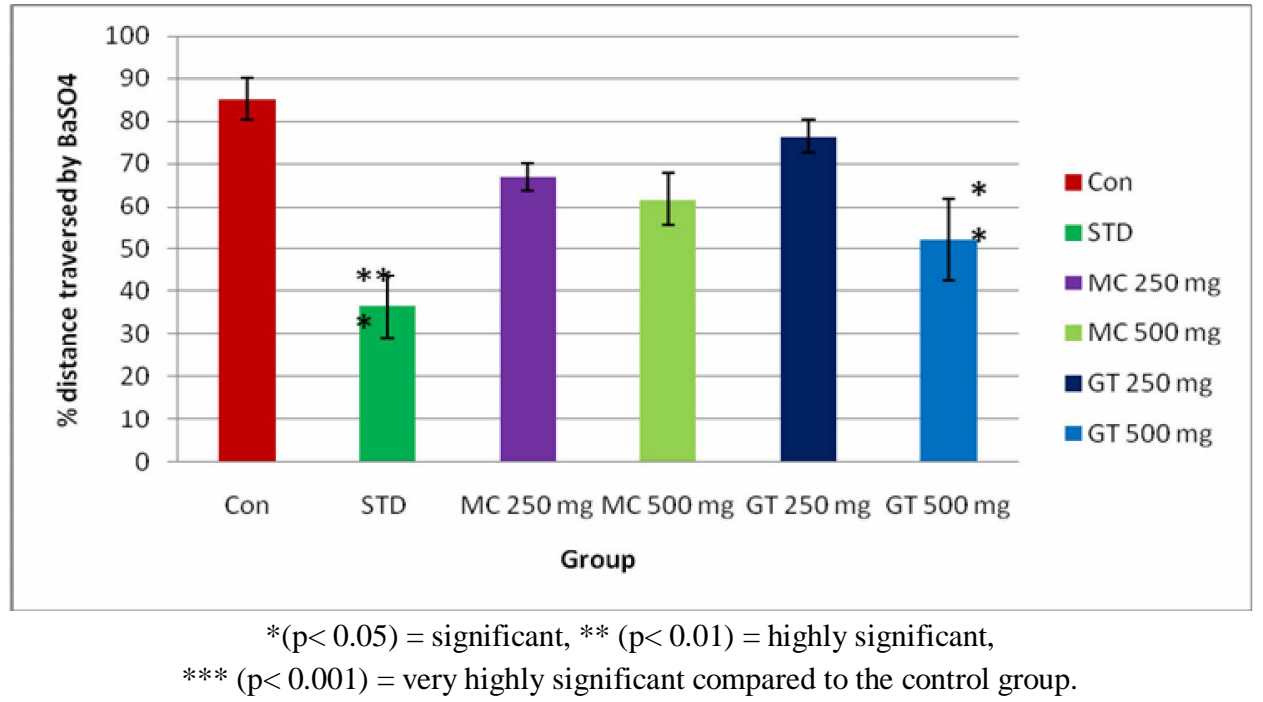

Figure 1. Effect of MC and GT extract on intestinal transit of barium sulfate milk in mice.

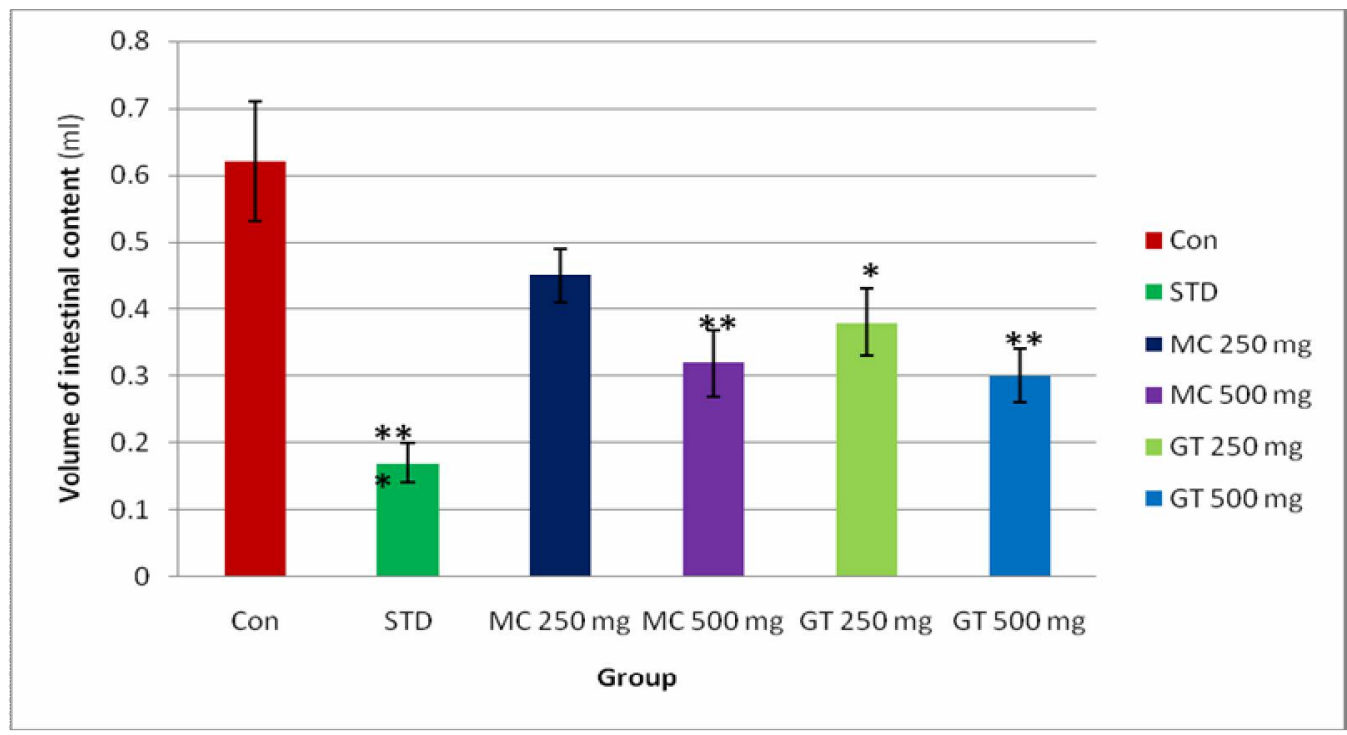

$*(\mathrm{p}<0.05)=$ significant, $* *(\mathrm{p}<0.01)=$ highly significant $* * *(p<0.001)=$ very highly significant compared to the control group.

Figure 2. Effect of MC and GT extract on castor oil-induced fluid accumulation. 
Antidiarrheal activity assessment by castor oilinduced fluid accumulation: The effect of tested plant extracts on the intestinal transit is depicted in figure 2. In this method, the mean volume of intestinal fluid and $\%$ inhibition of intestinal fluid accumulation as compared to control group was measured. Castor oil administration caused a substantial increase of fluid accumulation in mice. The administration of MC at $250 \mathrm{mg} / \mathrm{kg}$ slightly $(27.42 \%)$ reduced the fluid accumulation but $\mathrm{GT}$ at $250 \mathrm{mg} / \mathrm{kg}$ reduced fluid accumulation by $38.71 \%$ which was significant ( $<<0.05$ ). Both MC and GT extract at $500 \mathrm{mg} / \mathrm{kg}$ dose produced a marked reduction $(48.39 \%$ and $51.61 \%$ respectively) in castor oil-induced fluid accumulation in mice which was highly significant $(\mathrm{p}<0.01)$ as compared to the control group (Figure 2). No extract group was comparable with standard loperamide (10 $\mathrm{mg} / \mathrm{kg}$ ) treated group in the reduction of intestinal fluid volume.

\section{Discussion}

Diarrhea results from an imbalance between the absorptive and secretory mechanisms in the intestinal tract, which is accompanied by an excess loss of fluid in the faces (Gaginella and Bass, 1978). Diarrhea is a common and major public health problem among people with poor standard of hygiene especially in developing countries and it remains the leading cause of morbidity and mortality in all age groups (Farthing, 2002). Martinez et al. (1998), based on the results from their investigation, concluded that herbal treatments remain important as home remedy for diarrhea. Heinrich et al. (2005) also reported that despite the availability of simple and cheap modern treatments for diarrhea (ORT), healers and patients in many communities still rely on locally available phytomedicines. These findings formed the basis of our present screening of various plants, including $M$. corchorifolia and G. thomsonii, for antidiarrheal activity.

Castor oil is a triglyceride and several mechanisms had been previously proposed to explain the diarrheal effect of castor oil (Gaginella and Bass,
1978; Altman, 2001) which stimulates the peristaltic activity as well as generation of giant contractions of the intestine and transverse and distal colon, leading to the changes in the electrolyte $\left(\mathrm{Na}^{+}\right.$and $\left.\mathrm{Cl}^{-}\right)$ permeability of the intestinal mucosa (Palombo, 2006) and generates massive contractions in transverse and distal colon (Croci, 1997). The ethanol extract of MC and GT showed no significant effect at $250 \mathrm{mg} / \mathrm{kg}$ dose but revealed highly significant effect at $500 \mathrm{mg} / \mathrm{kg}$ dose in castor-oil induced diarrhea.

Magnesium sulfate $\left(\mathrm{MgSO}_{4}\right)$, acting as laxative, causes myogenic contraction of intestinal smooth muscle to achieve laxative effects. Their laxativetic action is also believed to result from osmotically mediated water retention, which then stimulates peristalsis. $\mathrm{MgSO}_{4}$ may stimulate the release of cholecystokinin, which leads to intraluminal fluid and electrolyte accumulation and to increased intestinal motility (Pasricha, 2006). We examined the diarrheal score and total number of feces during 4 hours after $\mathrm{MgSO}_{4}$ administration on mice. Ethanolic extract of MC and GT showed no significant effect in 250 $\mathrm{mg} / \mathrm{kg}$ dose. The MC extract showed highly significant effect and GT demonstrated highly significant effect at $500 \mathrm{mg} / \mathrm{kg}$ dose in $\mathrm{MgSO}_{4}$ induced diarrhea.

Barium sulphate passage test is commonly used to determine the effect of the test substances on gut motility. It increases the volume of the intestinal content by preventing the reabsorption of water. It also promotes the liberation of cholecystokinin from duodenal mucosa, which increases the secretion and motility of small intestine and also prevents the reabsorption of $\mathrm{NaCl}$ and water. Barium sulfate induced diarrhea is presumed to be by osmotic properties and cholecystokinin production (Galvez et al., 1993). Ethanolic extract of MC and GT showed slight reduction of GI motility at $250 \mathrm{mg} / \mathrm{kg}$ dose. However, GT extract showed highly significant effect at $500 \mathrm{mg} / \mathrm{kg}$ dose in $\mathrm{BaSO}_{4}$ induced GI motility test. A decrease in the motility of gut muscles increases the stay of substances in the intestine. This allows better water absorption. It is therefore presumed that 
the reduction in the intestinal propulsive movement in the barium sulphate model may be due to antispasmodic properties of the extracts.

One of the main causes of diarrhea is water retention in the intestine (enter pooling) and agents such as castor oil and prostaglandin $\mathrm{E}_{2}\left(\mathrm{PGE}_{2}\right)$ are known to increase enter pooling (Havagiray et al., 2004; Perianayagam et al., 2005; Robert et al., 1976; Mascolo et al., 1994). In this study, castor oil was administered to prepare a pathologic rat model of abnormal enter pooling. The castor oil treated control group had significant increase in enter pooling. The ethanolic extract of MC at $500 \mathrm{mg} / \mathrm{kg}$ dose and GT at both doses displayed statistically significant decreasing tendency. The loperamide $10 \mathrm{mg} / \mathrm{kg}$ positive control group also exhibited significant improvement.

\section{Conclusion}

The results of the present study indicate that $M$. corchorifolia and $G$. thomsonii are potential therapeutic option in the effective management of diarrhea that have potent inhibitory action on gastrointestinal movement and secretion, thus justifying its widespread use by the local population for these purposes. Although the specific mechanisms of action of the extract need to be explored, the antidiarrheal effect of the extract could be related to inhibition of secretion, reducing intraluminal fluid accumulation or enhancing water absorption but not delaying motility. Concerted efforts are being made to fully investigate the mechanisms involved in the pharmacological activities of $M$. corchorifolia and $G$. thomsonii and phytochemical studies are also in progress to isolate and characterize the active constituents of the plants. The isolated compounds may serve as useful prototypes of antidiarrheal drugs of natural origin possessing the desired pharmacological activities while lacking certain untoward effects.

\section{References}

Afroz, S., Alamgir, M, Khan, M.T.H., Jabbar, S., Nahar, N. and Choudhuri, M.S.K. 2006. Antidiarrhoeal activity of the ethanol extract of Paederia foetida Linn. (Rubiaceae). J. Ethnopharmacol. 105, 125-130.
Ajaib, M., Khan Z., Khan N. and Wahab M. 2010. Ethno botanical studies on useful shrubs of district Kotli, Azad Jammu and Kashmir, Pakistan. Pak. J. Bot. 42, 1407-1415.

Altman, D.F., 2001. Drugs used in gastrointestinal diseases. In: Katzung, B.G. (Ed.), Basic and Clinical Pharmacology, $8^{\text {th }}$ edition, McGraw-Hill, San Francisco, pp. 1070-1071.

Bhakuni, R.S., Shukla, Y.N. and Thakur, R.S. 1986. Cyclopeptide alkaloids from Melochia corchorifolia. Phytochemistry, 26, 324-325.

Bhakuni, R.S., Shukla, Y.N. and Thakur, R.S. 1991. Melochicorine, a pseudooxindole alkaloid from Melochia corchorifolia. Phytochemistry, 30, 31593160.

Chopra, R.N., Nayar, S.L. and Chopra, I.C. Glossary of Indian Medicinal Plants. CSIR, New Delhi; 1956.

Croci, T., Landi, M., Emonds-Alt, X., Fur, G.L., Maffrand, J.P. and. Manara L. 1997. Role of tachykininsin castor oil diarrhoea in rats. British J. Pharmacol. 121, pp. 375-380.

Damiki, L. and Siva, H. 2011. Ethnomedicinal plants used for diarrhea by tribals of Meghalaya, Northeast India. Pharmacog. Rev. 5, 147-154.

Doherty, S.S. 1981. Inhibition of arachidonic acid release, mechanism by which glucocorticoids inhibit endotoxin induced diarrhoea. British J. Pharmacol. 73, 549-554.

Encyclopedia of Life; www.gbif.org (assessed on 05.05.2019)

Ezeja, M.I. and Anaga, A.O. 2010. Antidiarrheal activities of Cochlospermum planchonii (Hook f). Intl. J. Toxicol. Pharmacol. Res. 2, 40-44.

Farthing, M.J.G. 2002. Novel targets for the control of secretory diarrhea. Gut. 50, 15-18.

Gaginella, T.S. and Bass, P. 1978. Laxatives: an update onmechanism of action. Life Sci. 23, 1001-1010.

Galvez, J., Zavzuelo, A., Crespo, M.E., Lorente, M.D., Ocete, M.A. and Jimenez, J. 1993. Anti-diarrhoeic activity of Euphorbia hirta extract and isolation of an active flavonoid constituent. Planta Med. 59, 333-336.

Gilani, A.H. and Rahman, A. 2005. Trends in ethnopharmacology. J. Ethnopharmacol. 100. 43-49.

Guerrant, R.L., Van G.T., Steiner, T.S., Theilman, M.N., Slutsker, L. and Tauxe, R.V. 2001. Practice guidelines for the management of infectious diarrhea. Clin. Infect. Dis. 32, 331-335.

Havagiray, R.C., Ramesh, C. and Dadhna, K. 2004. Studies on anti-diarrheal activity of Calotropis gigantea R.Br. in experimental animals. J. Pharma. Sci. 7, 70-75. 
Heinrich, M., Heneka, B., Ankli, A., Rimpler, H., Sticher, O. and Kostiza, T. 2005. Spasmolytic and antidiarrhoeal properties of the Yucatec Mayan medicinal plant Casimiroa tetrameria. J. Pharm. Pharmacol. 57, 1081-1085.

Herbal Medicine Research Centre, Institute of Medical Research, Kuala Lumpur. 2002. Compendium of Medicinal Plants Used in Malaysia. 2, p.134.

Imam, M.Z., Sultana, S. and Akter, S. 2012. Antinociceptive, antidiarrheal and neuropharmacological activities of Barringtonia acutangula. Pharmaceut. Biol. 50, 1078-1084.

India Biodiversity Portal, www.gbif.org (assessed on 05.05.2019)

Jebunnessa Uddin, S.B., Mahabub-Uz-Zaman, M., Akter, R. and Ahmed NU. 2009. Antidiarrheal activity of ethanolic bark extract of Mitragyna diversifolia. Bangladesh J. Pharm. 4, 144-146.

Maikere-Faniyo, R., Van P.L., Mutwewingabo, A. and Habiyaremye, F.X. 1989. Study of Rwandese medicinal plants used in the treatment of diarrhea. $J$ Ethonopharmacol. 26, 101-109.

Martinez, H., Ryan, G.W., Guiscafre, H. and Gutierrez, G. 1998. An intercultural comparison of home case management of acute diarrhea in Mexico: implications for program planners. Arch. Med. Res. (Mexico, D.F.) 29, 351-360.

Mascolo, N., Izzo, A.A., Avtore, G., Barboto, F. and Capasso, F. 1994. Nitric oxide and castor oil induced diarrhea. J. Pharmacol. Exper. Thera. 268, 291-293.

Mia A.W. and Ghani, A. 1990. In: Ghani A (ed), Traditional Medicine, Pharmacy Department, Jahangirnagar University, Savar, Dhaka, Bangladesh, pp. 10-12.

OECD guidelines for the testing of chemicals (acute oral toxicity - Up and down procedure) [Last cited on 2013 Dec 09]. Available from: http://www.oecd.org

Ouyang H. and Chen, J.D.Z. 2004. Review article: therapeutic roles of acupuncture in functional gastrointestinal disorders, Aliment. Pharmacol. Therapeut. 20, 831-841.

Palombo, E.A. 2006. Phytochemicals from traditional medicinal plants used in the treatment of diarrhoea: Modes of action and effects on intestinal function. Phytother. Res. 20, 717-724.
Pasricha, P.J. 2006. In: Goodman \& Gillman's The Pharmacological Basis of Therapeutics, $11^{\text {th }}$ Edition, McGraw-HILL Publishers, New York. Treatment of Disorder of Bowel Motility and Water Flux; AntiEmetics; Agents Used in Biliary and Pancreatic Disease. Chapter 37, p.992.

Perianayagam, J.B., Narayanan, S., Gnanasekar, G., Pandurangan, A., Raja, S. and Rajagopal, K.. 2005. Evaluation of antidiarrheal potential of Emblica officinalis. Pharmaceut. Biol. 43, 373-377.

Raja, N., Babu, A., Dorn, S. and Ignacimuthu, S. 2001. Potential plants for protecting stored pulses from Callosobruchus maculatus (Coleoptera: Bruchidae) infestation. Biol. Agri. Horticul. 19, 19-27.

Rao, B.G., Rao, Y.V. and Rao, T.M. 2013. Hepatoprotective and antioxidant capacity of Melochia corchorifolia extracts. Asian Pac. J. Trop. Med. 6, 537-543.

Robert, A., Nezamis, .J.E., Lancaser, C., Hanchar, A.J. and Klepper, M.S. 1976. Enteropooling assay; a test for diarrhea produced by prostaglandins. Prostaglandins. 11, 809-828.

Saalmüller, L. and UeberdiefettenSäuren des Ricinusöls. 1848. On the fatty acids of castor oil. Justus Liebigs Ann. Chem. 64, 108-126.

Saralaya, M., Patel, P., Patel, M., Roy, S.P. and Patel, A.N. 2010. Anti-diarrheal activity of methanolic extract of Moringa oleifera Lam roots in experimental animal models. Int J Pharm Res. 2, 35-39.

Shukla, K. 2009. Bioassay: An uncomplicated methodology for ensure safety of Traditional Formulations. Res. J. Pharmacog. Phytochem. (RJPP). 1, 1-4.

Sini, J.M., Umar, I.A., Anigo, K.M., Stantcheva, I., Bage, E.N. and Mohammed, R. 2008. Antidiarrheal activity of aqueous extract of Combretum sericeum roots in rats. Afr. J. Biotech. 7, 3134-3137.

The Global Biodiversity Information Facility: GBIF Backbone Taxonomy, 2013-07-01 (http://www.gbif.org/species/ 3152125, assessed on 2013-11-21).

Thripati, R.C., Pandey, M.B., Singh, S. and Pandey, V.B. 2010. Antifungal flavonoids of Melochia corchorifolia. J. Indian. Chem. Soc. 87, 511-512.

Tschesche, R. and Reutel, I. 1968. Alkaioide aus sterculiaceen, I: Über Peptidalkaloide aus Melochia corchorifolia. Tetrahedron Lett. 9, 3817-3818. www.efloras.org (assessed on 05.0.2019) 